\title{
LETRAS EM OFICINA: A AFIRMAÇÃO RETUMBANTE DO "NÃO"
}

\author{
Simone Moschen Rickes e Paulo Gleich \\ Universidade Federal do Rio Grande do Sul, Porto Alegre, Brasil
}

RESUMO: Partindo do recorte do percurso de uma oficinante, assídua frequentadora da Oficina de Escrita que se realiza semanalmente no Hospital Psiquiátrico São Pedro de Porto Alegre, o presente artigo interroga, desde a Psicanálise de Freud e Lacan, as relações existentes entre negação, agressividade e simbólico. A elaboração tem como horizonte refletir sobre a produção da perda como um dos operadores do trabalho em oficina junto a sujeitos que encontraram importantes impasses em sua estruturação.

PALAVRAS-CHAVE: psicanálise, oficina de escrita, negação, agressividade, simbólico.

\section{LETTERS IN WORKSHOP: THE RESOUNDING AFFIRMATION OF "NO"}

\begin{abstract}
Based on an outline of a participant's course in a writing workshop - which is held weekly in São Pedro Psychiatric Hospital, located in Porto Alegre - the present article questions, from the view of Freud's and Lacan's psychoanalysis, the existing relations between negation, aggressiveness and the symbolic. This work's horizon is to reflect on the production of lack as one of the operators of the making in workshops with subjects that encountered important impasses in their structuring.
\end{abstract}

KEYWORDS: psychoanalysis, writing workshop, negation, aggressiveness, symbolic.

Uma mancha rasga a paisagem monocromática do Hospital Psiquiátrico. O prédio centenário, cujas paredes presenciaram muitas cenas, abriga hoje, em uma de suas alas, a Oficina de Criatividade. Nela desdobra-se um trabalho que tem como horizonte dar lugar a diferentes modos de produção de si e do mundo para os que neste espaço ancoram seu fazer - participantes das oficinas e trabalhadores oriundos de diversas formações, quais sejam, psicólogos, pedagogos, artistas plásticos, educadores físicos... No espaço híbrido das oficinas terapêuticas, diferentes profissionais encontram lugar para desdobrar as insuficiências de seus saberes frente à loucura e a necessidade de inventar as condições para a produção de um compartilhamento através de um fazer comum: pintura, costura, bordado, escultura, entre outros. Da frequência a este lugar fazem parte tanto internos do hospital quanto ex-internos, pacientes em atendimento ambulatorial e outros membros da comunidade.

À volta de uma grande mesa encontram-se, semanalmente, os participantes da Oficina de Escrita. Alguns deles sentam-se desde $2004 \mathrm{em}$ torno deste artefato que, ao mesmo tempo em que os une, cria uma separação entre eles. Há os que preferem estar não tão perto e por isso se alojam na periferia deste círculo, montando seu acampamento num lugar em que não se sintam potencialmente invadidos pelas frases, conversas e olhares que por ali circulam.

No espaço da Oficina de Escrita os participantes são convidados a deixar suas marcas sobre o papel, a produzir um registro possível, um traço singular que diga algo de sua subjetividade. A escrita produzida neste território, assim como seus habitantes, é plural: encontramos ali palavras que contam sonhos, delírios e histórias do passado, ou que juntas compõem poesias e músicas. Em outros escritos, leem-se palavras que seguem regras próprias de agrupamento, formando listas, frases aleatórias, registros repetidos de um nome, o abecedário, números, símbolos de um código próprio ou rabiscos e garatujas.

O que reúne os participantes da Oficina não é o propósito de produzir um livro, um conto ou algum outro produto socialmente valorizado. Menos ainda se trata, ali, de ensinar o bom uso do idioma - mesmo que, para alguns de seus frequentadores, aquele espaço de escrita lhes remeta à escola. O propósito da Oficina é oferecer, através de lápis, caneta, papel e escuta, a possibilidade de cada sujeito formular um registro próprio, de acordo com sua singularidade e com suas possibilidades. Essa produção é feita, em sua maioria, em cadernos, o que possibilita aos oficinantes terem uma casa para seus registros. $\mathrm{O}$ fato de que esses registros podem ser retomados por quem os produz é uma das características que dão especial contorno a este espaço, pois inscreve uma experiência incomum na fluidez sem detenção do grande manicômio. Se no dia-a-dia muitos internos demonstram precisar proteger seus pertences, levando-os junto ao corpo para que não sejam furtados, confiscados, destruídos, na Oficina encontram um lugar 
onde deixar uma parte sua que sempre será reencontrada, independentemente do que ali produzam ou da forma que a frequentem.

No território desta mesa não está em jogo apenas o registro de algo previamente dado, "guardado" no sujeito, e que ali poderia ganhar expressão. Naquele espaço, busca-se tecer as condições para que os sujeitos possam armar uma posição de enunciação frente a si, aos oficineiros, aos outros participantes, à comunidade. Cada sujeito, nesse trabalho de invenção de si, se relaciona com as camadas em que o outro/Outro ${ }^{1}$ se lhe apresenta e que lhe são possíveis, naquele momento, acessar. Assim, a Oficina de Escrita, paradoxalmente, conta com participantes letrados, artífices de poetas, contadores de história, compositores de canções, mas também com habitantes analfabetos, cegos, mudos... O que os liga não é o compartilhamento de uma posição mais ou menos homogênea no uso das letras, mas a paixão pelas perspectivas que elas lhes abrem - mesmo quando delas não fazem o uso canônico.

Os oficineiros, em vez de professores ou peritos que transmitem algo de seu saber aos que frequentam a Oficina, buscam atuar como pescadores de desejo, guiados pela ética da psicanálise. Quem, de alguma forma, é fisgado por aquilo que lhe é oferecido escreve, rasga a superfície monocromática da folha e é interpelado pela diferença que ali introduziu. Nessa pescaria, há várias iscas diferentes, que precisam ser constantemente lançadas e testadas: ora uma sugestão de tema, ora uma música, ora uma imagem. Não há garantias de que uma dessas iscas funcione com todos, assim como não há certeza de que ao mesmo peixe apeteça sempre a mesma isca. Sendo assim, a Oficina é um espaço que precisa de constante reinvenção para se sustentar, para permitir que seus movimentos encontrem eco e que as ações que nela acontecem possam reverberar. Da mesma maneira, seus integrantes necessitam, semanalmente, investir algo de seu desejo para dela seguirem participando.

O território da Oficina de Escrita tem os contornos de uma topologia bastante singular: localiza-se no dentro/fora do Hospital. Seja porque acolhe tanto moradores da instituição como membros da comunidade, seja porque a lógica que ordena as relações naquele espaço resiste aos modos de laço com o outro prevalentes em uma instituição secular como é o Hospital. Em contraste com uma relação marcada pela dicotomia - paciente/médico, louco/normal, ensinante/aprendente - desdobra-se ali uma dança de posições que acaba por dissolver a fixidez dos papéis constantemente reafirmados. O dispositivo da oficina tem a peculiaridade de buscar fazer circular o lugar do saber. Na dinâmica que ali se estabelece, a isca pode ser lançada por um dos participantes-oficinantes, os comentários que permitem dar andamento ao trabalho podem vir da atendente res- ponsável pela manutenção, a pergunta que abre espaço à enunciação de uma angústia pode ser dirigida pelo colega nas letras... Assim, questiona-se incessantemente o lugar do saber e do poder que a lógica manicomial fossilizou na figura do especialista - seja ele o médico, o psicólogo, o professor ou qualquer outro "doutor".

\section{O que a oficina pode nos ensinar}

$\mathrm{Na}$ dança de lugares da Oficina de Escrita, Maria apresentava-se de modo bastante uniforme. Apesar de sentar-se à mesa com duas colegas de unidade, com as quais frequentava o espaço, e de ter seu próprio caderno, havia algo que a distinguia, perceptível não apenas em sua mudez, mas em seu olhar e na forma em que se colocava no grupo, quase como uma sombra. Em seu caderno fazia, linha após linha, uma série de garatujas, como se escrevesse como as demais. Ocasionalmente, levantava os olhos da folha dirigindo-se ao oficineiro, como que o convocando. Mas este, incapaz de "ler" o que ela the oferecia, apenas fazia sinal de "ok" para demonstrar que estava vendo seu trabalho e para incentivar que continuasse.

O ritual se repetia encontro após encontro. Maria chegava, silenciosa, entre as outras, sem dirigir ao oficineiro mais que alguns olhares furtivos. Sentava-se, esperava que lhe fosse entregue seu caderno e começava a escrever somente depois que fosse colocada a data na folha. Necessitava que o gesto do outro inaugurasse um espaço em que estivesse autorizada a transitar, mimetizando a escrita de suas companheiras.

Não nos passam despercebidas, nessa necessidade de Maria, as formulações lacanianas acerca da estruturação psíquica que o acompanhamento dos seus caminhos e descaminhos na Oficina tem nos permitido pensar e indagar. É sobre os efeitos estruturantes ${ }^{2}$ deste trabalho em oficina que pretendemos refletir no âmbito deste artigo, e sobre isso temos aprendido, e muito, com Maria, tal como Freud diz ter aprendido a psicanálise com a famosa paciente de Breuer, Anna O.

Sabemos, ao revisitar a história da psicanálise, que o corte epistemológico que esta operou, no que tange ao tratamento e à compreensão dos quadros psicopatológicos, teve seu momento inaugural quando da inserção de uma diferença discreta, mas de consequências retumbantes, na abordagem das pacientes histéricas da época: o deslizamento do ver ao escutar. Com esse movimento, Freud inventa o dispositivo da escuta. Não que até então não se ouvissem os pacientes - na verdade, fazia-se isso muito pouco -, mas com Freud a escuta é o instrumento de intervenção do analista. Vale observar que esta mudança na forma de intervir foi decisivamente influenciada pelos próprios pacientes, como se estes mostrassem o melhor caminho a seguir, encontrando no 
Dr. Sigmund o acolhimento e a ousadia necessários para percorrê-lo. Acerca do tratamento de Anna O., lemos nos Estudos sobre a Histeria (1893/1974c, pp. 64-65): "Ela descrevia de modo apropriado esse método, falando a sério, como uma 'talking cure', ao mesmo tempo em que se referia a ele, em tom de brincadeira, como 'chimney-sweeping'. A paciente sabia que, depois que houvesse dado expressão a suas alucinações, perderia toda a sua obstinação..." Maria, nossa Anna O., tem nos ensinado sobre os efeitos do trabalho em oficina e o quanto esse trabalho pode contribuir à construção de uma suplência às funções que não puderam ser inscritas ao longo da história de alguns sujeitos.

\section{Uma porta para as letras}

Duplamente excluída, pela ausência de fala e de letras, Maria limitava-se a mimetizar o que se desenrolava naquela mesa. Sua presença, porém, não era inerte, nem sua ausência de palavras, silenciosa. Com seu olhar, inquiria de forma barulhenta o oficineiro, que registrava o desconforto daquele que se sente indagado em uma língua que não é capaz de compreender, quanto mais de responder. Também deixava uma marca em sua escrita muda, pelo avesso de uma ausência de letras: sua mão, apoiada sobre o caderno, criava uma margem, um contorno singular para aquela produção - escrevia seu corpo na folha.

Tomado de certa angústia por aquelas linhas que refletiam o silêncio de Maria no grupo, o oficineiro resolveu introduzir uma marca outra, que não a data, naquela folha: escreveu o nome de nossa inquiridora na primeira linha e apontou, com gestos, que aqueles riscos a representavam. Parecendo surpresa, Maria olhou primeiro para o oficineiro, depois para o caderno; hesitou, como que esperando algo, mas após alguns instantes recomeçou suas garatujas. Imbuído de um espírito de aposta - inspiração comum aos que trabalham no território da Oficina -, o oficineiro não se deu por vencido; voltou a arriscar e, tomando a mão de Maria, escreveu, com ela, com traço trêmulo e desajeitado, o nome dela. Novamente Maria hesitou, e novas garatujas brotaram na folha. Depois de mais uma tentativa a duas mãos, o oficineiro apostou em outro caminho: indicou, com gestos, que escrevesse sozinha. Surpresa! A uma primeira tentativa com letras ilegíveis, seguiu-se uma segunda, já mais próxima das letras que compõem seu nome - tão próxima que nos fez pensar que Maria já havia transitado pelas letras em outro momento, mas tinha sido deportada desse território. A habilidade que mostrava ao reproduzir seu nome em muito transcendia a daqueles que se colocam nesta empreitada pela primeira vez.

Resolveu-se então introduzir outras palavras, para tentar evitar cair em nova repetição automatizada. Após uma tentativa com uma palavra-isca que pareceu não fisgá-la, o oficineiro indagou, com gestos, que palavra ela gostaria de escrever. Surpresa ainda maior: Maria respondeu, em alto e bom som, algo que soou como "pão!". Ainda tomado pelo inesperado de ouvir sua voz, duvidando de seus ouvidos, o oficineiro perguntou, repetindo a palavra e, com gestos, tentando mostrar-lhe o que havia entendido: "pão?". Maria repetiu os gestos e respondeu afirmativamente: "pão!", mostrando grande contentamento. Escreveu-se a palavra em seu caderno, sendo esta imediatamente copiada por Maria. A voz de Maria foi imediatamente percebida por Joana, participante cega da oficina, que em sua escuridão consegue perceber e registrar as sutilezas dos pequenos deslocamentos operados naquele espaço: "mas não é que a muda fala!", anunciou Joana para as colegas de mesa.

Alimentado pela palavra pão, o oficineiro passou então a escrever palavras que denominavam elementos do entorno, apontando para os objetos e lendo-as em voz alta, após o que Maria, não sem dificuldade, as repetia. Ao ir preenchendo a página do caderno, seu júbilo com a descoberta das letras - e da voz? - era visível, tanto no olhar como na excitação motora. Ria e alegrava-se ao ver que seus traços eram reconhecidos e que sua fala era compreendida. Ao final do encontro, levantou-se e, eufórica, disparou porta afora, fechando, para nos surpreender mais uma vez, a porta e o pesado portão de ferro que dão acesso à Oficina.

Certa feita, ao ser indagada sobre que palavra escrever em seu caderno, Maria apontou, com um gesto, para a porta por onde se entra na Oficina - aquela que impetuosamente fechara depois daquela sextafeira mágica. $\mathrm{O}$ oficineiro, querendo certificar-se do pedido, perguntou-lhe então, em voz alta, marcando bem as sílabas, "por-ta?", ao que Maria respondeu, confirmando: "por-ta!". Escrita a palavra no caderno, esta ganhou nova versão, pela mão de Maria, na linha abaixo. A porta que se abria para que Maria entrasse na Oficina passou também a ser a porta que abria a página para suas letras, pois, a cada semana, indagada sobre que palavra colocar em seu caderno, Maria apontava na direção da porta e, ao ser questionada se era mesmo à porta que se referia, repetia: "por-ta!".

Que o oficineiro não tenha aceitado de pronto sua interpretação do lugar para onde Maria havia apontado, mas tenha optado por certificar-se de sua leitura, diz de uma posição ética que não é qualquer. Ao perguntar a Maria sobre seu desejo, ele afirma, antecipando nela, a possibilidade de que enuncie algo próprio. $\mathrm{O}$ oficineiro antecipa e supõe um sujeito em Maria, tal como o adulto que, diante do pequeno ser, daquele que ainda não fala, pergunta sobre o que com ele se passa, para logo a seguir traduzir, fisgando, com as malhas da linguagem, sua manifestação inábil. Ele o fez não somente nesse 
momento, mas desde quando registrou seu desconforto diante do olhar de Maria, tomando-o como uma mensagem enigmática que não consegue decifrar. Há naquele olhar algo a ser lido, porém por muito tempo não se apresentava qualquer alternativa de resposta a este enigma. É somente a partir do reconhecimento da presença de uma mensagem e da antecipação de uma resposta, com a escrita do nome que tenta quebrar a série de garatujas, que se abre um espaço de troca. $\mathrm{O}$ oficineiro antecipa um sentido, mas não se descuida de registrar os efeitos desta antecipação em Maria, respeitando sua resposta, que por vezes alimenta sua aposta antecipada, e por vezes a desmente de forma a requerer nova aposta. De algum modo é assim que age o adulto diante do pequeno ser, quando se permite estar em uma posição de dúvida em relação ao significado das mensagens que ele emite.

Vale a pena fazer um pequeno desvio em nosso percurso com Maria para retomarmos alguns elementos propostos por Lacan $(1949 / 1998)$ sobre o estádio do espelho. Isso porque supomos que, no modo como o oficineiro estabelece a intervenção, está em jogo a tentativa de produzir as condições para que opere algo da alienação, momento que se constitui em plataforma de sustentação ao tempo de separação - este coincidente com o advento do sujeito. Porém, trata-se de uma alienação que inclui a possibilidade de separação através da dúvida ${ }^{3}$ que habita aquele que reconhece e antecipa um sentido à produção do outro. Mas prossigamos mais lentamente.

A observação de bebês na relação com seus cuidadores demonstra o quanto o adulto interroga a criança, supondo nela um querer e sua possibilidade de expressão. Ao ouvir o choro do pequeno, o adulto cuidador dirá: "Pedrinho, estás com fominha? Não? Não é isso? Ah! Estás querendo dar uma volta neste dia tão lindo. Vamos lá fora um pouquinho". A suposição da presença de um sujeito desejante abre espaço para que esse sujeito possa advir, ao passo que consiste também num sítio de alienação ao Outro primordial que sustenta essa antecipação. Esse paradoxo chega a beirar o absurdo, pois, no início de sua existência, o pequeno ser é no Outro; sem essa captura pelo Outro, ele sequer poderia manter-se vivo. A possibilidade de que ele deslize do auto-erotismo das reações reflexas para constituir-se como ser depende de uma "ação psíquica" que, conforme Lacan nos demonstrou, diz respeito ao enlace que aquele que suporta a função materna faz com o pequeno para situá-lo em um mundo de significações. Esse enlace, no entanto, acena com um horizonte de alienação no qual toda possibilidade de ser fica atrelada ao que este Outro possa colocar em jogo - proposição incômoda quando o que nos marca, na contemporaneidade, é o que Lacan (1959-60/1997, p. 19) jocosamente chamou de um "delírio de autonomia" que condensa dois ideais que nos organizam: o ideal de autenticidade e o ideal de não-dependência. Queremo-nos originais, autônomos, auto-fundados, representantes irresolutos do "self-made man", e, no entanto, nascemos como sujeitos alienados às condições de nomeação desdobradas pelo Outro primordial - condições que encontraram impasses para muitos dos frequentadores da Oficina de Escrita.

Lacan (1949/1998), ao retomar alguns estudos acerca da eficácia psíquica da imagem, deles se instrumentaliza para pensar a estruturação primeira do ser como resultado de uma identificação a uma imagem que lhe é antecipada no Outro. Ao deparar-se com a descrição constante na literatura de que a criança, ainda quando sua maturação neuromotora não the permite sustentar seu corpo sozinha, assume, diante do espelho, uma postura ereta acompanhada por uma expressão de júbilo ao reconhecer-se na imagem ali refletida, Lacan proporá este momento como sendo o de uma identificação àquilo que o Outro primordial reconhece como o sujeito. O reconhecimento da imagem como própria, por parte do pequeno ser, implica uma designação que venha de um outro: "este és tu". Assim, aquele que se ocupa do bebê acenará com uma imagem que antecipa, em muito, as possibilidades do pequeno ser, e este, por um movimento de identificação, ver-se-á ocupando o lugar que o Outro primordial lhe reserva. É na relação com aquele que sustenta para a criança, quando seu organismo ainda é pura dispersão, uma imagem unarizada, pondo em causa certa antecipação, que o eu se constituirá. Podemos encontrar aqui a ideia de Freud (1914/1974f) de que uma nova ação psíquica deve inscrever-se para que a construção do narcisismo - do eu - se coloque em marcha.

A imagem com a qual o Outro primordial acena para o pequeno ser é tramada desde antes de seu nascimento com os fios do desejo daqueles que dele se ocupam. Embora o infans ainda não tenha construído propriamente um passado, ele é herdeiro de significantes que marcaram os que o antecederam na cadeia das gerações, significantes estes que designam uma certa posição na qual ele é esperado. Se esta espera constrói um lugar de alienação para o sujeito, que o leva a ser nesta designação, é somente através dela, através da existência deste berço significante que serve de sustentação para o bebê, que lhe será possível, em outro tempo, enunciar algo em nome próprio. Se aqueles que estão no lugar de cuidar do pequeno ser se veem impossibilitados de endereçar-lhe um olhar desejante de antecipação, este, ao nascer, cai num vazio, não sendo enlaçado à trama significante.

Recolher esses elementos tecidos por Lacan faz sentido para pensarmos a experiência da Oficina, pois mesmo que seus participantes já estejam tão distantes do tempo da infância, supomos que muitos deles encon- 
tram-se enredados em impasses que não puderam ser transpostos naquele tempo da estruturação. Não encontraram quem lhes sustentasse uma nomeação alienante ou então se viram diante de uma palavra que funcionou como signo, imprimindo um lugar de onde jamais conseguiram sair. Sobre esta face e reverso da moeda nos fala Lacan (p. 95, 1955-56/1988) ao retomar o famoso texto de Freud sobre Schreber, eminente jurista alemão que registrou, através da escrita, seu delírio:

Num sujeito como Schreber as coisas vão tão longe que o mundo inteiro está tomado nesse delírio de significação, de tal modo que se pode dizer que, ao invés de estar só, quase nada há de tudo o que o cerca que, de certo modo, ele não seja. Em compensação, tudo o que ele faz existir nessas significações é de alguma maneira vazio dele próprio.

Ao trabalhar a alienação como operação fundante do ser, Lacan (1964/1985, p. 201) situa o sujeito nascente diante de uma escolha forçada: "A bolsa ou a vida! Se escolho a bolsa, perco as duas. Se escolho a vida, tenho a vida sem a bolsa, isto é, uma vida decepada". Interessante assinalar que, mesmo em um tempo no qual se presentifica uma posição com pouca margem de manobra, na medida em que escolher a bolsa seria a própria morte do sujeito, Lacan decide usar o termo escolha, o que, por certo, não é algo acessório para a compreensão da alienação. Mesmo em um momento de pura alienação, não estaria antecipada, em se tratando de uma estruturação neurótica, a possibilidade de separação, na medida em que a operação de que se trata é uma operação de escolha? Não foi a dimensão da escolha que se viu suspensa na produção de uma posição psicótica? É justamente a antecipação de uma condição de escolha que o oficineiro desdobra quando recoloca a pergunta sobre o que deve escrever: é mesmo às palavras "pão" e "porta" que Maria quer dar lugar no papel? Ele antecipa uma leitura, rastreando os sinais de Maria, mas não está certo de sua pertinência. Precisa certificar-se - operação que sempre deixa um resto de dúvida. O oficineiro se situa na relação com Maria de forma não-totalizante, mas como sendo ele mesmo marcado pela falta, falta esta que procura inscrever no laço com essa artesã das letras. Ele desdobra algo da alienação ao propor antecipadamente um sentido aos gestos de Maria, ao autorizar-se a escrever em seu caderno, a inscrever algo em seu espaço psíquico, mas o faz acompanhado pelo mal-estar daquele que é marcado pela falta e que, por isso, experiencia o abismo que há entre ele e a oficinante. Essa experiência dá lugar para que Maria possa cada vez mais tomar posse de seu sítio como separada do outro.

Na presença da dúvida vemos a marca da separação e os primórdios de sua introdução para o sujeito. O Outro primordial precisa mostrar algum sinal de incompletude, falibilidade ou deficiência para a separação se concretizar e para o sujeito vir a ser como \$; em outras palavras, o Outro primordial deve demonstrar que é um sujeito desejante (e dessa forma também faltante e alienado), que também se sujeitou à divisão da linguagem, para que testemunhemos o advento do sujeito. (Fink, 1998, p.76)

A assunção da falibilidade do saber daquele que está na posição de coordenador da Oficina desdobra, em ato, o princípio de separação, na medida em que ela mesma, a falibilidade, é efeito da apreensão de que aquele a quem se dirige é outro e, por isso, é portador de uma dimensão desejante não-transparente. Isso, que pode soar óbvio na intervenção junto aos sujeitos/ outros, estejam eles na instituição que estiverem, não é moeda corrente no Hospital. Numa visita à Unidade escuta-se uma atendente de enfermagem retrucar a uma paciente que se queixa de dor nas pernas: "Como assim, dor? Eu não tô sentindo nada...”!! É patente que a intervenção da atendente aponta como horizonte possível de diálogo uma alienação sem separação: se ela não sente, a paciente também não sente. Ou melhor, a paciente só sente o que ela for capaz de sentir, não representando, nesta medida, qualquer enigma para a atendente. Poder se situar como enigma frente ao outro é uma das operações que se quer propiciar aos participantes da Oficina.

Assim, aquilo que, estruturalmente, segundo Lacan (1955-56/1988), caracterizaria o sujeito em uma posição psicótica - uma certa captura na alienação ao Outro - parece ser reforçado por uma lógica que perpassa a instituição e aqueles que a representam. Nesta, valorizam-se a obediência, a disciplina e a docilidade, sendo as manifestações contrárias - ou seja, aquelas que diriam algo do sujeito - rechaçadas. Para um paciente, tentar excluir-se de tal posição de alienação é, também, colocar em jogo sua existência, pois é frequente que manifestações contrárias às esperadas encontrem-se com ameaças, muitas vezes perversas como "vou te envenenar", "vou te cortar em pedacinhos", e punições por "mau comportamento". Tal situação gera um impasse de difícil resolução: por um lado, a ameaça de exclusão imanente aos movimentos de descolamento desse Outro institucional; por outro, o custo psíquico que implica manter-se incluído.

Não é, portanto, sem riscos o movimento de diferenciação, de enunciação em nome próprio operado por Maria, já que, no cotidiano da Unidade, busca-se, frequentemente, a unidade, o todo, o apagamento das diferenças. De fato, não sabemos até que ponto aquilo que se ensaiou ao longo dos encontros da Oficina refletese no cotidiano de Maria, em sua relação com a equipe do Hospital - esse espelho que, à menor dissonância com a imagem antecipada, ameaça partir-se. Não há 
dúvidas, no entanto, de que, mesmo circunscrito ao espaço da Oficina, tal movimento tem seus efeitos, que se revelam na posição de Maria no grupo, agora não apenas como imitadora, mas como uma participante, cuja palavra também circula na mesa.

Lacan, pelo menos no acento que nos interessa tomar, não situa a referência à alienação-separação somente do lado do sujeito (enquanto este poderia ser pensado como uma certa expressão do indivíduo), mas naquilo que também se recorta, se produz, no lugar do Outro (enquanto este lugar pode ser pensado também como uma certa expressão coletiva, ou mesmo da cultura, do código, etc.) pelo encontro do sujeito. Assim, o campo do sujeito e o campo do Outro afetam-se mutuamente (Costa, 1998, p.27).

Com isso queremos ressaltar que o modo como os oficineiros se situam na Oficina, enquanto representantes do Outro, procura inscrever para os participantes possibilidades de que experienciem posições que no Hospital são obliteradas por um funcionamento que, mais do que qualquer coisa, faz intensificar a cronificação da posição alienada frente ao Outro.

O que pudemos até agora percorrer nos dá conta de que o estabelecimento de um sujeito do desejo como algo que se diferencia na relação ao Outro é fruto de uma estruturação que põe em cena a inscrição de uma fronteira sustentada por uma tensão entre alienação e separação, pontos de marcação de um limite. A presença de tais operadores de relação ao Outro não se dá de forma alternada, em que um excluiria o outro, mas ambos se compõem a cada movimento do ser. Tal composição dá contornos diferentes às fronteiras estabelecidas, alimentando com novos elementos, a cada momento, a delimitação sujeito/Outro.

Se na estruturação do sujeito trata-se de fronteiras, a referência reiterada de Maria à porta - desde seu gesto de fechá-la, marcando a separação física do outro, até seu gosto por escrevê-la - nos fala de um modo de operar esta tentativa de desenhar um limiar. Após seus avanços nas letras, não apenas o trabalho de Maria na Oficina havia mudado. No caminho da Unidade à Oficina, como que com pressa de chegar, ela passara a adiantar-se às colegas, que não conseguiam acompanhar seu passo rápido. $\mathrm{Na}$ Oficina, mostrava-se impaciente para começar o trabalho e chamava a atenção dos oficineiros se estes se demoravam demais em escrever a palavra desejada. Ria com grande contentamento ao enunciar uma palavra que era reconhecida pelos outros e observava os movimentos que se davam na mesa, ora rindo junto, ora fazendo brincadeiras com os oficineiros e colegas. Outro detalhe, percebido pelos oficineiros, pareceu indicar essa mudança em seu laço com a Oficina e com as letras: passou a circular pelo Hospital não mais na companhia da bolsa que sempre usara, mas de uma pasta de estudante.

\section{O "não" e sua afirmação retumbante}

Das colegas de Unidade e de Oficina, era Violeta quem aparentava ter uma ligação mais estreita com Maria. Sempre eram vistas juntas na Unidade, no pátio do Hospital, na Oficina. Violeta parecia fazer as vezes de porta-voz de Maria: não raro, enunciava o que Maria sentia ou queria dizer ("ela está com ciúmes", "ela quer um cigarro"). Tinha, às vezes, algo de maternal: dizia frases como "que bonitinha a mudinha", "coitadinha da mudinha". Maria parecia limitar-se a acompanhá-la, aceitando o laço que Violeta estabelecia para ela com os demais, através de sua fala.

Ao longo do trabalho com Maria, pequenos sinais foram apontando para uma mudança nessa relação: Violeta passou a trazer à Oficina queixas de que Maria a agredira, de que estava braba com ela, de que não queria dar-lhe cigarros. Notava-se certo estranhamento entre as duas, na fala de Violeta e nos olhares enviesados que Maria ocasionalmente lhe dirigia. A fissura dessa relação explicitou-se na Oficina quando, ao ver Violeta fazer movimentos sedutores em direção ao oficineiro, Maria emitiu, espontaneamente, um sonoro "NÃO!", acompanhado de uma careta de raiva. Daí em diante, passaram a ser cada vez mais frequentes as manifestações de agressividade de Maria em relação a Violeta, que se mostrava surpresa com a mudança da colega. Maria agora lhe endereçava "nãos", gestos de desprezo, grunhidos e caretas.

A agressivização da relação de Maria com Violeta e o concomitante surgimento do "não" foram por nós comemorados. Muito embora tenham dado certo trabalho no que diz respeito ao manejo da relação entre elas, começava a esboçar-se do lado de Maria um corte em relação àquela que, por muito tempo, parecia ter sustentado uma imagem que se oferecia como duplo, permitindo à Maria circular pelos espaços do Hospital. Uma distância, inscrita pela linguagem - um sonoro e rotundo "não" -, ganhava lugar no laço ao semelhante.

Também aqui Lacan nos traz um aporte teórico valioso, ao pensar a função da agressividade para a estruturação do eu. Ao tomar o "não!" de Maria como representante da agressividade, podemos entrever sua função para o psiquismo do sujeito: ele barra, põe uma borda, um limite àquilo que vem do outro como demanda ou como leitura unívoca. A porta, tantas vezes apontada, tantas vezes escrita, desliza para uma outra apresentação: "não!”. Um não/porta que nos diz dos ensaios de trânsito pelo lugar do eu. Conforme nos ensina Lacan (1948/1998, p. 116),

desde a origem o eu se afigura marcado por essa relatividade agressiva ... é dela que nasce a tríade do outro, do eu e do objeto, que, fendendo o espaço da comunhão especular, inscreve-se nela segundo um 
formalismo que the é próprio.... como não conceber que cada grande metamorfose instintiva a escandir a vida do indivíduo irá novamente questionar sua delimitação [grifo nosso] ... ?

Na metamorfose operada por Maria ao deslocar-se de seu eu de muda e analfabeta, de par aquiescente na relação com as colegas, fez-se imperativa a recriação dos contornos dessa delimitação, para que pudesse sustentar sua nova posição frente ao outro que insistia em jogá-la de volta a seus antigos contornos. Se aquilo que produzia e que, ao ser lido pelos oficineiros, lhe permitia ocupar esse novo lugar não era reconhecido por aquelas que compartilhavam seu cotidiano, precisava defenderse com unhas e dentes para não voltar à condição com a qual Violeta lhe acenava. Na falta de uma linguagem mais consistente, que lhe permitisse articular discursivamente essas questões, seu "não" se fazia acompanhar de grunhidos, gestos de desprezo, socos.

\section{Na origem, a expulsão - do "não" como estruturante do simbólico}

Muito embora os movimentos de Maria na Oficina nos falem de tentativas, nem sempre felizes, de construir suplência a uma estruturação cujos impasses mostram seus efeitos a céu aberto, seus desdobramentos, como referimos, ensinam-nos sobre e, mais do que isso, remetem-nos às elaborações que, desde Freud, fazem-se presentes, na história da psicanálise, sobre o advento do simbólico. Revisitar os percursos de Maria na Oficina nos serve de catapulta para lançarmo-nos na retomada das elaborações de Freud e Lacan sobre o lugar da negação como estruturante do simbólico. Com isso não queremos dizer que, ao trabalhar/escrever na Oficina, Maria tenha franqueado sua cidadania no quadrante do simbólico. Observamos, sim, em seus percursos, efeitos que situamos como sendo de suplência, oriundos de um encontro com o outro que inclui a distância que a separação inscreve. Mas tomemos o trabalho com Maria como ponto de partida, como mote, para pensar sobre a tecedura entre negação, agressividade e simbólico.

Em 1925, Freud publica um artigo denominado A Negativa (Die Verneinung). Trata-se de um texto curto que, embora bastante tardio em relação aos chamados Escritos sobre a técnica, que datam de 1914-15, foi incluído, por muitos comentaristas, nesse conjunto de textos. Isso talvez se deva ao fato de que, ao iniciar o trabalho, Freud chama atenção para um fenômeno bastante comum na clínica, a saber, a inscrição na fala do paciente de algo que ele supõe ser a ideia que ao analista ocorre naquele momento para, logo a seguir, desmenti-la. Exemplifica Freud (1925/1975, p. 373): "'O senhor pergunta quem pode ser essa pessoa no sonho. Não é a mãe'. Emendamos isso para: 'Então é a mãe" ". Do que se deriva a importante dica clínica de desprezar a negação que acompanha o pensamento do paciente, para dele reter apenas o conteúdo.

Afora o que no artigo referido possa referir-se ao "manejo da técnica", algo vai nos interessar, e muito, se estamos empenhados em seguir a gênese do sujeito e sua relação com a negação. O interrogante que organiza o escrito se centra em delimitar as condições que permitem a um sujeito dizer "isso é meu, isso sou eu" e "isso é do outro, isso é o outro", ou seja: como se produz uma primeira experiência do interno e do externo, do dentro e do fora? Vemos aqui aparecer a referência à negação como condição de possibilidade de uma primeira inscrição desta experiência. Mas examinemos melhor esta questão...

Freud vai (re)construir uma história, que de forma alguma pretende ser a metáfora de um desenvolvimento, mas sim uma referência a um momento inicial, mítico, em que, para o sujeito, por um lado, tudo que lhe confere prazer, que é por ele sentido como bom, equivaleria àquilo que se encontra dentro dele e, por outro, tudo o que é da ordem do desconforto, do mau, seria sentido como sendo-lhe exterior. Trata-se de um momento primordial no qual vemos atuar o eu-prazer a incorporar o que lhe dá prazer e a expulsar o que lhe confere desprazer.

Há, no começo, parece dizer Freud - mas 'no começo' não quer dizer outra coisa, no mito, senão 'era uma vez'... Nessa história, era uma vez um eu (entenda-se, aqui, um sujeito) para quem ainda não havia nada de estranho. A distinção entre o estranho e ele mesmo é uma operação de expulsão [grifo nosso] (Hyppolite, 1966/1998, p. 898).

Assim, se é possível ao sujeito referir-se a um fora como distinto dele próprio, é porque houve, em algum momento, uma primeira operação de expulsão capaz de produzir essas duas instâncias numa certa tensão - dentro/fora; eu/não-eu. Isso porque, de início, é preciso imaginar um tempo em que essa tensão não existia. Esse mecanismo que Freud chamou de juízo de atribuição, ou seja, a capacidade do sujeito de decidir sobre as características de algo, inscreve-se a partir de uma expulsão que funda duas instâncias em tensão, em um momento segundo em relação ao que seria o da pura unidade, no qual ainda não se verificaria a existência de um eu e de um não-eu ${ }^{5}$. A negação (expulsão) aparece como subsequente a esse momento inaugural enquanto fundadora da tensão eu/não-eu.

Retomemos especialmente as seguintes palavras de Hyppolite (1966/1998, p. 898): "a distinção entre o estranho e ele mesmo é uma operação de expulsão". Neste trecho, o autor estabelece uma divisão entre "ele mesmo", um sujeito, e o estranho. Freud (1919/1974e) 
havia se dedicado longamente ao tema do estranho. Em seu artigo intitulado Das Unheimliche, traduzido

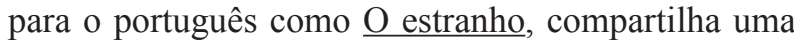
detida pesquisa etimológica na qual encontrou-se com uma interessante peculiaridade: o vocábulo familiar (heimlich), por vezes, não se diferencia daquilo que poderíamos localizar como sua antítese, a palavra estranho ( $\underline{\text { unheimlich}) . ~ " H e i m l i c h ~ e ́ ~ u m a ~ p a l a v r a ~ c u j o ~ s i g-~}$ nificado se desenvolve na direção da ambivalência, até que finalmente coincide com o seu oposto, unheimlich. Unheimlich é, de um modo ou de outro, uma subespécie de heimlich" (1919/1974e, p. 283). Se heimlich pode apresentar duas vertentes de significação, primeiro o que é familiar ou agradável e, segundo, o que se mantém fora da vista, o que se refere à esfera da intimidade, o un de unheimlich marca a oposição somente a seu primeiro significado. Estranho diz respeito, também, ao que está fora do alcance de visão e que, de repente, faz-se ver. A referência ao escópico é central na elaboração desse conceito que Freud tece com elementos que retém de sua leitura de um conto de E. T. A. Hoffmann, $\underline{\mathrm{O} \text { Homem }}$ $\underline{\text { da Areia }}^{6}$. Tal referência não nos passa despercebida no que concerne a uma tessitura possível entre esse texto e o artigo de Lacan sobre o estádio do espelho. Ambos trabalhos vão nos fornecer elementos para pensar a centralidade do duplo na constituição do sujeito.

Nesse artigo de 1919, Freud se dedica a pensar os meandros da presença do duplo na constituição subjetiva. Para Freud, o duplo consiste em uma imagem especular que serve, nos primórdios da estruturação psíquica, de sustentador frente ao desamparo no qual a condição de dependência deixa o pequeno ser. Impossível não reconhecer aí as teorizações de Lacan sobre o estádio do espelho, que situam o duplo como a imagem que o Outro primordial oferta ao pequeno para que, a partir dela, germine algo que irá ganhar forma como eu. Nos primórdios da estruturação psíquica, o duplo se apresenta como uma salvaguarda narcísica contra a aniquilação, o despedaçamento. O duplo é uma "criação que data de um estágio mental muito primitivo, há muito superado - um estágio em que o duplo tinha um aspecto mais amistoso (Freud, 1919/1974e, p. 295)".

Para Freud, o trânsito do narcisismo primário ao secundário introduziria, como em uma operação matemática, uma inversão do sinal no caráter desse duplo que, de "uma garantia da imortalidade, transforma-se em estranho anunciador da morte" (Freud, 1919/1974e, p. 295). Assim, em um primeiro momento, o duplo oferece uma imagem na qual ancorar-se, na qual projetar, especularmente e de forma unarizada, aquilo que ainda se encontra disperso. Em um segundo momento, no entanto, quando já constituído como sujeito, quando já operando na tensão alienação-separação, tal imagem aparece como ameaça de morte, de retorno à condição de objeto.
Nossa incursão pelo tema do duplo se entretece ao testemunho da relação estabelecida entre Violeta e Maria. A função que Violeta parecia exercer para Maria de companhia constante na Oficina - e, aparentemente, também fora dela - e de tradutora de seu silêncio nos remete às elaborações freudianas sobre o duplo. Se, num primeiro momento, Maria parecia precisar desse duplo para poder circular e fazer um laço com aqueles que a rodeavam, a partir do momento em que foram sendolhe oferecidas leituras menos especulares, que incluíam em seu gesto a possibilidade do equívoco, o trânsito por novos lugares de enunciação foram timidamente emergindo. Nesse novo cenário, a imagem do duplo, daquele que tudo sabe sobre o sujeito, daquele que fala em seu lugar - encarnada por Violeta -, passou a apresentarse, em muitos momentos, como ameaça de retorno à objetalização, condição de morte psíquica de um sujeito marcado pela fragilidade daquilo que é inaugural.

Interessante também pensar na distinção, referida por Hyppolite (1966/1998), que se estabelece entre "o estranho e ele mesmo", pois isso nos aponta, se pensado com os elementos do texto freudiano de 1919, para uma espacialidade peculiar: se, por um lado, o estranho emerge de uma distinção, por outro, o estranho está incluído neste que é ele mesmo. O estranho se faz sentir no reencontro com um resto daquele momento em que havia continuidade entre sujeito e Outro, um momento anterior a uma expulsão primeira que, pelo retorno, mostra sua dimensão de inacabamento. O estranhamento faz apontar para o caráter de contingência desta operação inaugural, para a sua não-inscrição como um destino inelutável do sujeito, para a sua dimensão de não-garantia. E mais, se o estranho é efeito de algo que retorna para o sujeito, e se a expulsão primeira produz uma cisão entre "ele mesmo" e o estranho, esta inscreve, na verdade, uma cisão interna ao próprio sujeito, uma distinção que diz respeito àquilo que lhe é Outro, mas que o habita. O estranho encontra-se incluído no "interior" do sujeito, sua experiência atualiza o caráter constitutivo e de construção da operação de divisão sujeito / Outro, bem como revela a sua não-garantia de perenidade, ou melhor, a sua necessidade de refundação a cada passo. Referida inexistência de garantia está estreitamente ligada à sensação de desamparo mencionada por Freud (1919/1974e) como passível de acompanhar o fenômeno do estranho.

Sami-Ali (1993, p. 31) refere que a sensação de "inquietante estranhamento 7 parece inseparável de uma estrutura particular do espaço, estrutura que permite que o objeto se manifeste e que rege tanto a forma como o conteúdo do conto" O Homem da Areia. É a partir também do trabalho com o conto e com o texto de Freud que o autor vai propor a presença de um espaço de inclusões recíprocas como antecedendo a experiência 
de um espaço que garante uma descontinuidade entre dentro e fora. Para o autor, podemos construir a ideia de uma experiência originária do espaço onde impera a bidimensionalidade, onde dentro e fora não são cindidos por uma relação que impede a continuidade entre ambos, onde a distância eu/outro não se faz presente e onde o conteúdo pode, paradoxalmente, conter o continente. São germinadas neste território as ideias de devoramento pelo alimento presentes em algumas formações delirantes.

o equacionamento do familiar e do estranho não pode se efetuar no espaço tridimensional, mas num campo espacial desprovido de profundidade, onde a atividade perceptiva opera segundo princípios diferentes do da realidade.... Disso resulta uma organização espacial que se assemelha ao espaço especular, onde o sujeito se apreende como um outro e onde o outro é a imagem do sujeito: mundo da metamorfose do mesmo (SamiAli, 1993, p. 37).

É por obra de um lançar fora, de uma operação em que algo se cospe para um exterior, que o espaço se inscreve como tridimensional. Aqui lembramos novamente Freud (1920/1974b), que, em Além do princípio do prazer, descreve a brincadeira de seu neto (então com um ano e meio de idade), na qual este arremessava um carretel, para logo em seguida puxá-lo de volta - o famoso jogo do fort/da. Para Freud, inscrevia-se ali, simbolicamente, a separação da mãe: o carretel, ao percorrer o espaço, desenha a sua profundidade, inscreve a sua dimensão terceira e inaugura um lugar "entre" que serve de laço e de separação entre eu/outro. Esse ato de lançar fora se renova, em camadas, em uma série que parte de um momento mítico originário, no qual aquilo que causa desprazer é cuspido para longe, e deságua no momento em que o pequeno lança para longe o carretel/ mãe, dando força e inscrição à função simbólica que o estrutura. Não deixamos de perceber o entrelaçamento existente entre a construção desse espaço fora por obra de uma ação que carrega certa dose de agressividade e a construção de um vazio - uma negatividade? - deixado por aquilo que foi lançado para longe. Negação / agressividade / vazio se entretecem para dar lugar à rede simbólica que sustenta e constitui o lugar-sujeito.

Além de perguntar-se sobre a gênese do juízo de atribuição, como vimos anteriormente, Freud, no texto A negativa (1925/1974a), vai se debruçar sobre a origem do que chamou de juízo de existência, a saber, a capacidade do sujeito de assegurar-se da existência ou não de uma representação na realidade: "é evidente que uma precondição para o estabelecimento do teste de realidade consiste em que objetos, que outrora trouxeram satisfação real, tenham sido perdidos" (p. 299). A lembrança dessa passagem mais uma vez nos remete à negação, uma vez que, se o sujeito se encontra somente na presença do objeto, na sua afirmação, não lhe será viável construir a possibilidade do juízo de existência. Este somente se produz a partir de uma ausência, de uma negação do objeto. Será desde esta operação de negação que ao sujeito será possível empenhar-se no processo de procurar reencontrar o objeto perdido, ausente. É a negação do objeto primordial que cria o espaço para o teste da realidade. Será que poderíamos dizer que é a inscrição da negação que cria a realidade enquanto instância objetiva, passível de conhecimento? E mais, que a afirmação surge no a posteriori, e somente aí, como primeira em relação à negação?

A divisão primordial que institui uma tensão eu/ não-eu se inscreve, portanto, a partir de uma expulsão, do lançar para longe, da perda do objeto, que passa agora a habitar uma exterioridade em referência - e somente em referência - à qual o sujeito pode emergir. Assim, é possível dizer que na origem da constituição do não-eu como condição de existência do eu está uma operação de negação/expulsão que se desdobra em um tempo segundo em relação a um momento primeiro - primeiro se tomamos o a posteriori como regendo a temporalidade aí implicada - de unidade absoluta. Vemos, com isso, a estreita ligação existente entre a exterioridade e a operação de negação. Há um mútuo engendramento entre ambas no qual é difícil localizar uma causa e um efeito.

Ao retomar a afirmação de Freud de que a função do juízo só é possível a partir da criação do símbolo da negação, Hyppolite (1966/1998, p. 900) questiona:

"por que Freud não nos diz: o funcionamento do juízo se torna possível pela afirmação? É que a negação vai desempenhar um papel, não como tendência para a destruição, nem tampouco no interior de uma forma de juízo, mas como atitude fundamental de simbolicidade explícita" [grifo nosso].

É na criação do símbolo de negação, na sua inscrição psíquica que vemos desenhar-se o quadrante do simbólico, instância propriamente humana, dotada do poder de criação. Conforme Lacan (1954/1998, p.394): "na ordem simbólica, os vazios são tão significativos quanto os cheios; realmente parece, ao ouvir Freud hoje, que é a hiância de um vazio que constitui o primeiro passo de todo o seu movimento dialético". É a partir de uma primeira expulsão, de uma primeira negação, que se inscreve a tridimensionalidade onde pulsa ausência/ presença, suporte dos deslocamentos simbólicos.

Não nos surpreende, então, que o "não" enunciado por Maria se situe de uma forma tão contundente. Ele retumba pela sala da Oficina, ele reverbera na sua relação com Violeta. O fato de encontrar-se enroscada nas tramas que inscrevem o "não", por obra de uma expulsão primeira, como originário do simbólico, faz com que Maria precise, uma vez que o tenha enunciado, 
reafirmá-lo a cada passo, como forma de tentar mantê-lo vivo, operando como mediador possível entre ela e o outro, como mediador possível de seu trânsito pelas letras. É porque este "não" está no lugar de uma suplência que suas consequências não encontram permanência e precisam ser sustentadas a cada passo.

\section{Oficina de escrita: a produção de uma perda}

A morte nos traz a questão daquilo que nega o discurso, bem como de saber se é ela que introduz neste a negação. Pois a negatividade do discurso, na medida em que faz existir o que não está ali, remete-nos à questão de saber o que o não-ser, que se manifesta na ordem simbólica, deve à realidade da morte. (...) Nada existe senão sobre um fundo de ausência. Nada existe senão na medida em que não existe. (Lacan, 1954/1998, p.381 e p.394).

A série que vai da perda - da negação - ao simbólico e às condições de criação que dele derivam foi trabalhada por Freud (1908/1974d) no artigo Escritores Criativos e Devaneios, no qual estabelece uma estreita relação entre o brincar, a escrita e a criação. "O escritor criativo faz o mesmo que a criança que brinca. Cria um mundo de fantasia que ele leva muito a sério, isto é, no qual investe uma grande quantidade de emoção, enquanto mantém uma separação nítida entre o mesmo e a realidade" (p.151). Sabemos que o grande texto freudiano sobre o brincar, referido uma e outra vez por aqueles que se tomam pela pergunta sobre a inscrição do sujeito no simbólico, é Além do Princípio do Prazer, de 1920. Das consequências que tira da observação do vaivém do fort/da, como vimos anteriormente, podemos, na esfera de nossas perguntas, colocar em série: negação, vazio, simbólico - e, por que não, escrita. A relação entre estes termos é extremamente complexa e sabemos não ter dado conta da extensão deste intricado emaranhado. Nosso intento estabeleceu-se no sentido de apontar o entretecido que se trama entre esses operadores. Contextura esta que surgiu para nós a partir da reflexão que o testemunho da emergência do "não" retumbante de Maria, num espaço de letras, colocou quase como necessidade.

Lançar fora o carretel/mãe, acompanhado da vocalização fort, e puxá-lo para perto, acompanhado da vocalização da, exige que o pequeno sustente certa agressivização em sua relação ao Outro, agressivização capaz de, em função do trajeto desenhado pelo carretel no ar, inscrever no espaço a tridimensionalidade que permite o estabelecimento de um entre-lugar como ponto, a um só tempo, de ligação e de separação entre sujeito/Outro. Por conta desse gesto que desdobra a perda do objeto - carretel/mãe -, o sujeito carimba seu passaporte para o mundo da linguagem e passa a estruturar a realidade - e a si mesmo - em consonância com as suas leis.

A partir do que foi tecido até aqui, nos perguntamos: não poderia ser um dos horizontes, em uma oficina de escrita junto a sujeitos que encontraram impasses significativos em sua estruturação, fomentar e testemunhar a produção de uma negação, de uma perda - por seu potencial para abrir, mesmo que apenas uma fresta, para que o sujeito acesse o campo do simbólico onde se escreve o "entre" sujeito/Outro? Questão que o retumbante "não" de Maria nos auxilia a enunciar e que segue colocando como que um convite a relançar o carretel no processo infindo da simbolização, que permite estender os limites do humano.

\section{Notas}

1 "O que se tenta indicar com essa convenção de escrita é que, além das representações do eu e também das identificações imaginárias, especulares, o sujeito é tomado por uma ordem radicalmente exterior a ele, da qual depende, mesmo que pretenda dominá-la" (Chemama, 1995, p.156).

2 Quando nos referimos à efeitos estruturantes, estamos pensando na possibilidade de construção de uma suplência à funções que não se inscreveram ao longo da história de alguns sujeitos. Sobre isso vale lembrar Calligaris (1989): “A folha em branco (...) não é uma injunção e é mais do que uma disponibilidade. Poderia valer a pena pensar nos numerosos casos nos quais a pintura e a escritura abriram, para sujeitos psicóticos, o espaço de uma metáfora delirante viável. Também na importância para paranoicos de escrever o delírio constituído que os sustenta, até o ponto que se poderia pensar que um dos efeitos autoterapêuticos do delírio acaba sendo a significação de escritor, de autor que o sujeito se constrói” (Calligaris, 1989, p.121-122).

3 "A ética da dúvida deve partir do analista e incluir o analisante. Não se trata de 'chamá-lo à razão’ para preveni-lo contra as manifestações do inconsciente (ou contra as soluções de compromisso do pensamento automático), mas de levá-lo a duvidar de suas convicções, introduzindo-o aos poucos na lógica de uma outra razão, a lógica da razão inconsciente". (Kehl, 2002, p.146).

4 Tradução livre dos autores do texto original em alemão.

5 Vale aqui lembrar uma passagem do texto de Freud (1915) Os instintos e suas vicissitudes (As pulsões e seus destinos): "Originalmente, no próprio começo da vida mental, o ego é catexizado com as pulsões, sendo, até certo ponto, capaz de satisfazê-las em si mesmo.... Nessa ocasião, o mundo externo não é catexizado com interesse.... Na medida em que o ego é auto-erótico, não necessita do mundo externo, mas, em consequência das experiências sofridas pelas pulsões de autopreservação, ele adquire objetos daquele mundo, e apesar de tudo, não pode evitar sentir como desagradáveis, por algum tempo, estímulos pulsionais internos. Sob o domínio do princípio do prazer ocorre agora um desenvolvimento ulterior no ego. Na medida em que os objetos que lhes são apresentados constituem fontes de prazer, ele os toma para si próprio (...); e, por outro lado, expele o que quer que dentro 
de si mesmo se torne uma causa de desprazer" (p.157).

6 Trata-se de um conto fantástico em que a temática do escópico é central. Natanael, protagonista da história, vê-se atormentado com a lembrança do Homem de Areia, criatura que sua mãe evocava na hora de pôr os filhos para dormir, dizendo-lhes que este jogava areia nos olhos das crianças que ficavam ardidos e impossíveis de serem mantidos abertos devido à sua chegada. É a esse ser que Natanael identifica um amigo da família, Coppelius, cujas visitas sempre lhe foram muito enigmáticas e das quais presenciava o efeito perturbador em seu pai. Quando da morte misteriosa de seu pai, é a Coppellius que Natanael responsabiliza. Essa figura retorna em sua vida de diversas formas, especialmente ao se apaixonar pela boneca Olímpia cuja condição de autômato não era visível para ele. Coppelius, agora Coppola é um dos construtores de Olímpia. O conto joga com o que é mais evidente, porém, para o que, Natanael, com os olhos cheios de areia, é cego (Hoffmann, 1986).

7 Sami-Ali traduz unheimlich por inquietante estranheza.

\section{Referências Bibliográficas}

CALligARIS, C. (1989). Clínica diferencial das psicoses. Porto Alegre: Artes Médicas.

CHEMAMA, R. (1995). Dicionário de Psicanálise. Porto Alegre: Artes Médicas.

COSTA, A. M. (1998). A ficção do si mesmo - interpretação e ato em psicanálise. Rio de Janeiro: Companhia de Freud.

FINK, B. (1998). O sujeito lacaniano: entre a linguagem e o gozo. Rio de Janeiro: Zahar.

FREUD, S. (1974a). A negativa. In Edição Standard Brasileira das Obras Psicológicas Completas de Sigmund Freud (2 $2^{\mathrm{a}}$ ed., Vol. XIX, pp. 295-308). Rio de Janeiro: Imago. (Trabalho original publicado em 1925).

FREUD, S. (1974b). Além do princípio do prazer. In Edição Standard Brasileira das Obras Psicológicas Completas de Sigmund Freud (2a ed., Vol. XVII, pp. 15-85). Rio de Janeiro: Imago. (Trabalho original publicado em 1920).

FREUD, S. (1974c). Casos clínicos. Srta. Anna O. In Edição Standard Brasileira das Obras Psicológicas Completas de Sigmund Freud ( $2^{\text {a }}$ ed., Vol.II, pp. 57-78). Rio de Janeiro: Imago. (Trabalho original publicado em 1893-1895)

FREUD, S. (1974d). Escritores criativos e devaneios. In Edição Standard Brasileira das Obras Psicológicas Completas de Sigmund Freud (2 a ed., Vol. IX, pp.149-158). Rio de Janeiro: Imago. (Trabalho original publicado em 1908).

FREUD, S. (1974e). O “estranho”. Em Edição Standard Brasileira das Obras Psicológicas Completas de Sigmund Freud (2 ed., Vol. XVII, pp. 275-304). Rio de Janeiro: Imago. (Trabalho original publicado em 1919).

FREUD, S. (1974f). Sobre o narcisismo: uma introdução. In Edição Standard Brasileira das Obras Psicológicas Completas de Sigmund Freud ( $2^{\text {a }}$ ed., Vol. XVII, pp. 85-122). Rio de Janeiro: Imago. (Trabalho original publicado em 1914).
FREUD, S. (1975). Die Verneinung. Em Sigmund Freud Studienausgabe ( $9^{\mathrm{a}}$ ed.). Frankfurt am Main: Fischer. (Trabalho original publicado em 1925).

HYPPOLITE J. (1998). Comentário falado sobre a "Verneinung" de Freud. In LACAN, J., Escritos (pp. 893-902). Rio de Janeiro: Zahar. (Trabalho original publicado em 1966).

HOFFMANN, E. T. A. (1986). O homem da areia. Rio de Janeiro: Rocco.

KEHL, M. R. (2002). Sobre ética e psicanálise. São Paulo: Companhia das Letras.

LACAN, J. (1998). A agressividade em psicanálise. In Escritos (pp. 104-126). Rio de Janeiro: Zahar. (Trabalho original publicado em 1948).

LACAN, J. (1998). O estádio do espelho como formador da função do eu. In Escritos (pp. 96-103). Rio de Janeiro: Zahar. (Trabalho original publicado em 1949).

LACAN, J. (1998). Introdução ao comentário de Jean Hyppolite sobre a "Verneinung" de Freud. In Escritos (pp. 370-382). Rio de Janeiro: Zahar. (Trabalho original publicado em 1954).

LACAN, J. (1998). Resposta ao comentário de Jean Hyppolite sobre a "Verneinung" de Freud. In Escritos (pp. 383-401). Rio de Janeiro: Zahar. (Trabalho original publicado em 1966).

LACAN, J. (1988). As psicoses. Rio de Janeiro: Zahar. (Trabalho original publicado em 1955-56).

LACAN, J. (1997). A ética da psicanálise. Rio de Janeiro: Zahar. (Trabalho original publicado em 1959-60).

LACAN, J. (1985). Os quatro conceitos fundamentais da psicanálise (2ed.). Rio de Janeiro: Jorge Zahar. (Trabalho original publicado em 1964).

SAMI-ALI. (1993). Corpo real, corpo imaginário. Porto Alegre: Artes Médicas.

Simone Moschen Rickes é Doutora em Educação pela UFRGS, professora do Pós-graduação em Educação - UFRGS e do Pós-graduação em Psicologia Social e Institucional - UFRGS, Membro da Associação

Psicanalítica de Porto Alegre. Endereço para correspondência: Rua Paulo Gama 110, prédio 12.201, $7^{\circ}$. andar, sala 700-04. CEP 90046-060. Porto Alegre, RS. E-mail: simone.m.r@via-rs.net

Paulo Gleich é Graduando em Psicologia do Instituto de Psicologia da UFRGS, Bolsista PIBIC/UFRGS no projeto Oficinas terapêuticas - possibilidades e impasses de um trabalho gerúndio.

\section{Letras em oficina: a afirmação retumbante do "não"}

Simone Moschen Rickes e Paulo Gleich

Recebido em: 30/06/2008

Aceite em: 15/09/2008 